Research Article

\title{
Complex Formation of Nickel(II) and Copper(II) with Barbituric Acid
}

\author{
Naciye Türkel and M. Suat Aksoy \\ Department of Chemistry, Faculty of Arts and Sciences, Uludă̆ University, 16059 Bursa, Turkey \\ Correspondence should be addressed to Naciye Türkel; nturkel@uludag.edu.tr
}

Received 17 December 2013; Accepted 6 January 2014; Published 12 February 2014

Academic Editors: Z. Aydogmus and I. Zhukov

Copyright (C) 2014 N. Türkel and M. S. Aksoy. This is an open access article distributed under the Creative Commons Attribution License, which permits unrestricted use, distribution, and reproduction in any medium, provided the original work is properly cited.

\begin{abstract}
Equilibrium studies have been carried out on complex formation of $\mathrm{M}^{2+}$ ions $(\mathrm{M}=\mathrm{Ni}$ and $\mathrm{Cu}$ ) with $\mathrm{L}=$ barbituric acid (BA) in aqueous solution at $25.0 \pm 0.1^{\circ} \mathrm{C}$ and with an ionic strength of $I=0.10 \mathrm{M}\left(\mathrm{KNO}_{3}\right)$ in aqueous medium. The basicity of the ligand was also assessed by the determination of the dissociation constants of the ligand. The experimental $\mathrm{pH}$ titration data were analyzed with the help of the BEST computer program in order to evaluate the stability constants of the various species formed. The stability constants of the binary systems decrease in the order of $\mathrm{Cu}(\mathrm{II})>\mathrm{Ni}(\mathrm{II})$. Distribution diagrams for the species were drawn showing the concentrations of individual species as a function of $\mathrm{pH}$ by the SPE software program.
\end{abstract}

\section{Introduction}

Organotransition-metal complexes formed with biologically active ligands have attracted great attention in recent years. Studies of such complexes in biological systems can lead to a better understanding of the roles of these ligands and can also contribute to the development of metal-based chemotherapeutic agents. Pyrimidine ring-containing compounds can be found in nucleic acids, various vitamins, and coenzymes and they play an important role in many biological systems $[1,2]$. In nucleic acids, they are related to anticancer chemotherapeutic antimetabolites [3]. Pyrimidine metal complexes have been studied in recent years because of their great variety of biological activities such as antimalarial, antibacterial, antitumoral, antiviral activities, and so forth [4-10]. Despite the multitude of coordination complexes of pyrimidines, the organometallic chemistry of these ligands received little attention, mostly from Beck and coworkers $[11,12]$.

Barbiturates are the derivatives of barbituric acid (2,4,6trioxypyrimidine) (Scheme 1). These drugs are used for many reasons such as hypnotics, sedatives, or anesthetics $[13,14]$. They also affect the motor and sensory functions, and they are used as cures for anxiety, epilepsy, and other psychiatric disorders $[15,16]$. The production process of plastics and pharmaceuticals requires the uses of barbituric acid. Introduced as one of the first medical use of barbiturates, barbital diethylbarbituric acid is known as veronal, or diemal [17]. The first psychologically active drug, barbital or veronal was introduced in 1903 by E. Fischer [18]. Only a few barbiturates have anticonvulsant properties, although many of them have sedative-hypnotic attributes. However, most barbiturates cause convulsions at large doses. Phenobarbital (5 ethyl-5 phenyl barbituric acid) is used for the treatment of convulsive disorders [19]. 5,5-Diethylbarbituric acid $\left(\mathrm{H}_{2}\right.$ debarb) is a sedative-hypnotic, and even as a discontinued chemical, its low oil, water partition coefficient as a result of biological processes makes it interesting [18]. Because of their ability to coordinate with transition metals through carbonyl oxygen and one or both deprotonated oxygen atoms, and also because of their wide use in medicine, the synthesis of their metal complexes has received great interest.

Furthermore, it has been suggested that the presence of the metal ions in biological fluids could have a significant effect on the therapeutic action of drugs. Many diverse applications of metal species are aimed at understanding the 


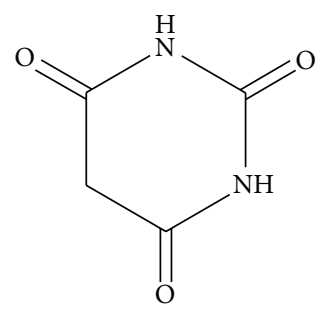

Scheme 1: Structure of the barbituric acid (BA).

natural roles of metal ions or exploiting the unique properties of metal centers in the study of the biology or biochemistry of nucleic acid and nucleic acid constitutes [2].

The literature review indicated that no work has been done on complex formation equilibria of this ligand in aqueous medium. There is only one study [20] of this ligand with $\mathrm{Cu}(\mathrm{II})$ and no work on the barbituric acid with $\mathrm{Ni}(\mathrm{II})$. They studied $\mathrm{Cu}(\mathrm{II})$ and $\mathrm{Fe}(\mathrm{II})$ complexation with the barbiturate ion by the solubility method, potentiometric titration, spectroscopy, and photometry. But they decided that the barbiturate anion was a monodentate ligand and calculated that Cubar ${ }^{+}$, stability constants was $\log \beta_{1}=3.07 \pm$ 0.01 by potentiometry [20]. So the objective of this work was to determine the stability constants of barbituric acid complexes with $\mathrm{Ni}(\mathrm{II})$ and $\mathrm{Cu}(\mathrm{II})$ metallic ions.

\section{Experimental}

2.1. Chemicals. Barbituric acid (BA) was obtained from Merck Chem. Co. $\mathrm{Ni}\left(\mathrm{NO}_{3}\right)_{2} \cdot 6 \mathrm{H}_{2} \mathrm{O}$ was provided by Aldrich Chem. Co. and $\mathrm{Cu}\left(\mathrm{NO}_{3}\right)_{2} \cdot 3 \mathrm{H}_{2} \mathrm{O}$ was provided by Merck $\mathrm{Chem}$. Co. All reagents were of analytical quality and were used without further purification. For the solutions, $\mathrm{CO}_{2}$-free double-distilled deionized water was obtained through the ultrawater purification system.

2.2. Titration Procedure. Solutions of metal ions $(0.01 \mathrm{M})$ were prepared from $\mathrm{Ni}\left(\mathrm{NO}_{3}\right)_{2} \cdot 6 \mathrm{H}_{2} \mathrm{O}$ and $\mathrm{Cu}\left(\mathrm{NO}_{3}\right)_{2} \cdot 3 \mathrm{H}_{2} \mathrm{O}$ received and standardized with ethylenediaminetetraacetic acid (EDTA) [21]. $\mathrm{HCl}$ stock solution was prepared from concentrated $\mathrm{HCl}$ and their concentration was determined with standardized $\mathrm{NaOH}$. All potentiometric titrations were carried out on solutions in a $100 \mathrm{~mL}$ double-walled glass vessel using titroline automatic titration system, which interfaces to a PC, with a $10 \mathrm{~mL}$ syringe, a Schott $\mathrm{pH}$ combination electrode, the temperature was controlled at $25.0 \pm 0.1^{\circ} \mathrm{C}$ by circulating water from a constant-temperature bath. The cell was equipped with a magnetic stirrer and a tightly fitting cap, which contained three holes for the combined electrode, nitrogen gas, and automatic burette. The emf was measured under nitrogen atmosphere. The ligand concentrations varied in $2 \times 10^{-3}-6 \times 10^{-3} \mathrm{M}$. The cell was standardized with two primary buffers. The buffer solutions were $\mathrm{pH}=4.0$ and $\mathrm{pH}=$ 7.0. The electrode was calibrated on the $-\log _{10}\left[\mathrm{H}^{+}\right]$ scale by titration of a $0.01 \mathrm{M} \mathrm{HCl}$ solution (adjusted to $I=$ $0.1 \mathrm{M}$ by adding $\mathrm{KNO}_{3}$ ) with carbonate free $0,1 \mathrm{M} \mathrm{NaOH}$ at $25 \pm 0.1^{\circ} \mathrm{C}$. The electrode slope calculated from the formula
$K=\left(E_{\mathrm{pH} 1}-E_{\mathrm{pH} 2}\right) /(\mathrm{pH} 2-\mathrm{pH} 1)$ was close to the Nernstian value $59.16 \mathrm{mV}$ (pHunit) $^{-1}$ within $>99 \%$. The emf readings were converted into hydrogen concentration. The $\mathrm{p} K_{\mathrm{w}}$ of water was calculated at ionic strength of $0.1 \mathrm{M}$ to be 13.97.

The acid dissociation constants of the ligands were determined potentiometrically by titrating the ligand $(50 \mathrm{~mL})$ solution $\left(2 \times 10^{-3}-6 \times 10^{-3} \mathrm{M}\right)$ of constant ionic strength $0,1 \mathrm{M}$, adjusted with $\mathrm{KNO}_{3}$. The stability constants of the binary complexes were determined by titrating $50 \mathrm{~mL}$ of a solution mixture of metal(II) $(\mathrm{Ni}(\mathrm{II})$ or $\mathrm{Cu}(\mathrm{II}))\left(2 \times 10^{-3} \mathrm{M}\right)$, the ligand $\left(2 \times 10^{-3}-6 \times 10^{-3} \mathrm{M}\right)$, and $0,1 \mathrm{M} \mathrm{KNO}_{3}$. One hundred titration points were collected at one titration. All titrations were performed in a purified $\mathrm{N}_{2}$ atmosphere, using aqueous $0.1 \mathrm{M} \mathrm{NaOH}$ as titrant.

The overall stability constants $\left(\beta_{p q r}\right)$ are defined as follows (charges are omitted for simplicity):

$$
\begin{gathered}
p \mathrm{M}+q \mathrm{~L}+r \mathrm{H} \rightleftharpoons\left[\mathrm{M}_{p} \mathrm{~L}_{q} \mathrm{H}_{r}\right] \\
\beta_{p q r}=\frac{\left[\mathrm{M}_{p} \mathrm{~L}_{q} \mathrm{H}_{r}\right]}{[\mathrm{M}]^{p}[\mathrm{~L}]^{q}[\mathrm{H}]^{r}},
\end{gathered}
$$

where $\mathrm{M}$ is a metal ion, $\mathrm{L}$ is the ligand, $\mathrm{H}$ is the proton, and $r$ is the respective stoichiometric coefficient. Calculations were performed using the computer program BEST [22] on a personal computer.

The stoichiometries and the stability constants of the complexes formed were determined by trying various possible composition models for the system studied. The concentration distribution diagrams were obtained using the program SPE [22].

\section{Result and Discussion}

Although the dissociation constants of barbituric acid have already been reported, we determined them under our experimental conditions by potentiometric titration in the $\mathrm{pH}$ range 1.8-12.0. The BEST computer program was used for calculations [22]. The obtained values are listed in Table 1 together with the literature data for comparison. A good agreement with earlier published data for BA is obtained [23] considering the differences in an ionic strength. The BA forms three species in aqueous solution, denoted by $\mathrm{H}_{2} \mathrm{~L}, \mathrm{HL}$, and L. Consider

$$
\begin{gathered}
\mathrm{H}_{2} \mathrm{~L} \rightleftharpoons \mathrm{HL}^{-}+\mathrm{H}^{+} \quad K_{\mathrm{a} 1}=\frac{\left[\mathrm{HL}^{-}\right]\left[\mathrm{H}^{+}\right]}{\left[\mathrm{H}_{2} \mathrm{~L}\right]} \\
\mathrm{HL}^{-} \rightleftharpoons \mathrm{L}^{-}+\mathrm{H}^{+} \quad K_{\mathrm{a} 2}=\frac{\left[\mathrm{L}^{-}\right]\left[\mathrm{H}^{+}\right]}{\left[\mathrm{HL}^{-}\right]} .
\end{gathered}
$$

3.1. Stability Constants of Ni(II)-BA Complexes. Potentiometric $\mathrm{pH}$ titrations of $\mathrm{Ni}(\mathrm{II})$ were performed at $1: 1,1: 2$, and $1: 3$ metal/ligand molar ratios at $25.0 \pm 0.1^{\circ} \mathrm{C}$ in an $0.10 \mathrm{M}$ $\mathrm{KNO}_{3}$ ionic medium. BA acid (solid) was added to the $\mathrm{Ni}(\mathrm{II})$ solutions with a metal/ligand molar ratio of $1: 1,1: 2$, and $1: 3$. Representative potentiometric titration curves for the $\mathrm{Ni}(\mathrm{II})$ BA complexes with $1: 1,1: 2$ and $1: 3$ stoichiometry are shown 
TABLE 1: Acid dissociation constants of Barbituric acid (BA) and the stability constants of the $\mathrm{Ni}(\mathrm{II}), \mathrm{Cu}(\mathrm{II})$ - $\mathrm{BA}$ complexes $\left(25.0 \pm 0.1^{\circ} \mathrm{C}\right.$, $\left.I=0.1 \mathrm{M} \mathrm{KNO}_{3}\right)$.

\begin{tabular}{lcrrc}
\hline Equilibrium & Constant & $\mathrm{BA}$ & $\mathrm{Ni}(\mathrm{II})$ & $\mathrm{Cu}(\mathrm{II})$ \\
\hline $\mathrm{H}_{2} \mathrm{~L} \rightleftharpoons \mathrm{HL}^{-}+\mathrm{H}^{+}$ & $\log K_{\mathrm{H}_{2} \mathrm{~L}}$ & $3.89 \pm 0.04$ & & \\
& & $(3.78)[23]$ & & \\
$\mathrm{HL}^{-} \rightleftharpoons \mathrm{L}^{-2}+\mathrm{H}^{+}$ & $\log K_{\mathrm{HL}}$ & $11.90 \pm 0.04$ & & \\
\hline \multirow{2}{*}{$\mathrm{M}+q \mathrm{~L}+r \mathrm{H}^{-} \rightleftharpoons\left[\mathrm{M}_{p} \mathrm{~L}_{q} \mathrm{H}_{r}\right]$} & $\log \beta_{110}$ & & $6.62 \pm 0.09$ & $8.39 \pm 0.05$ \\
& $\log \beta_{120}$ & & $11.65 \pm 0.03$ & $14.16 \pm 0.06$ \\
& $\log \beta_{131}$ & & $17.94 \pm 0.04$ & $19.20 \pm 0.04$ \\
\hline
\end{tabular}

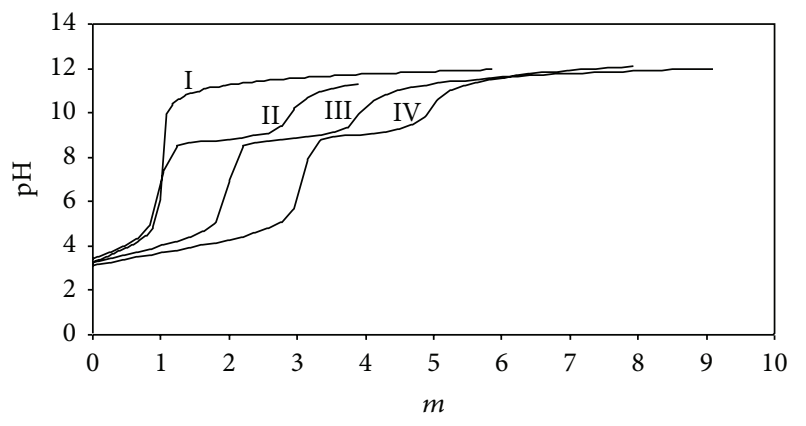

FIGURE 1: Potentiometric $\mathrm{pH}$ profiles for solutions containing (I) BA, $T_{\mathrm{BA}}=2.0 \times 10^{-3} \mathrm{M}$ and $\mathrm{Ni}(\mathrm{II})$ and $\mathrm{BA}$ in the ratios, (II) $1: 1\left(T_{\mathrm{Ni}}=\right.$ $2.0 \times 10^{-3} \mathrm{M}$ and $\left.T_{\mathrm{BA}}=2.0 \times 10^{-3} \mathrm{M}\right)$, (III) $1: 2\left(T_{\mathrm{Ni}}=2.0 \times 10^{-3} \mathrm{M}\right.$ and $\left.T_{\mathrm{BA}}=4.0 \times 10^{-3} \mathrm{M}\right)$, and (IV) $1: 3\left(T_{\mathrm{Ni}}=2.0 \times 10^{-3} \mathrm{M}\right.$ and $\left.T_{\mathrm{Ni}}=6.0 \times 10^{-3} \mathrm{M}\right)$, respectively, $T=25.0 \pm 0.1^{\circ} \mathrm{C}$ and $I=0.1$ $\mathrm{MKNO}_{3}$.

in Figure 1 for BA systems together with the titration curve for the free ligand (BA). Analysis of the complexed ligand curves (Figure 1) indicates that the addition of metal ion to the free ligand solutions shifts region of the ligand to lower $\mathrm{pH}$ values. This shows that complex formation reactions proceed by releasing protons from BA. Two inflection points were observed at $m=1,0$ and $m \sim 2,2$ on the titration curves of the $1: 1 \mathrm{Ni}(\mathrm{II})-\mathrm{BA}$ systems (Curve 2 in Figure 1), where $m$ is the number of moles of base added per mole of the metal (Figure 1). Experimental data has shown that, in the $m=0$ to $\sim 2.2$, the NiL complex forms between $\mathrm{pH}=6.0-11.0$. BA ligand acts as a bidentate chelating ligand via the negatively charged imino $\mathrm{N}$ atom and one of the carbonyl $\mathrm{O}$ atoms, adjacent to the imino $\mathrm{N}$ atom.

The potentiometric titrations of the $1: 2 \mathrm{Ni}(\mathrm{II})$-BA systems were carried out under the same experimental conditions. In these curves, two inflection points were observed at $m=1.8$ and $m=3.8$. The titration of these protons in each of these systems indicates that the $\mathrm{NiL}_{2}$ complex forms gradually. The second BA was bound as the same the first BA.

The potentiometric titrations of the $1: 3 \mathrm{Ni}(\mathrm{II})$-BA systems were carried out under the same experimental conditions. The titration of these protons in each of these systems indicates that the $\mathrm{NiL}_{3} \mathrm{H}$ complex forms gradually. But in the third BA molecule it was bound only once via the negatively charged imino $\mathrm{N}$ atom or one of the carbonyl $\mathrm{O}$ atoms. In the $1: 3$ molar ratio potentiometric titrations, the stability constants of the complexes $\mathrm{NiL}, \mathrm{NiL}_{2}$, and $\mathrm{NiL}_{3} \mathrm{H}$ were calculated by the BEST computer program [22]. The stability constants of their complexes are given in Table 1.

The distribution diagrams were drawn in the titration where the metal to ligand mole ratio was $1: 3$. They were obtained with the aid of SPE program [22] and the concentration of total metal ion present $\sim 2 \times 10^{-3} \mathrm{M}$ set at $100 \%$. In Figure 3 the species $\mathrm{NiL}_{3} \mathrm{H}$ for the system $\mathrm{BA}$ and metal ion $\mathrm{Ni}(\mathrm{II})$ reaches a maximum of $100 \%$ at $\mathrm{pH} 10,0$. The second species $\mathrm{NiL}_{2}$ reaches a maximum of $10 \%$ at $\mathrm{pH} 7,0-12,0$ and $\mathrm{NiL}$ complex species in the mole ratio of 1 moles of ligand to one mole metal, presents a maximum of $70 \%$ near $\mathrm{pH} 6,0$.

3.2. Stability Constants of $\mathrm{Cu}(\mathrm{II})-\mathrm{BA}$ Complexes. The potentiometric titrations of the $\mathrm{Cu}(\mathrm{II}): \mathrm{BA}$ systems were performed at $25.0 \pm 0.1^{\circ} \mathrm{C}$ in an $0,10 \mathrm{M} \mathrm{KNO}_{3}$ ionic medium. $\mathrm{BA}$ acid was added to the $\mathrm{Cu}$ (II) solutions with a molar ratio of $1: 1,1: 2$, and $1: 3$. Two inflection points were observed at $m=1.0$ and $m \sim 2.2$ on the titration curves of the $1: 1 \mathrm{Cu}(\mathrm{II})-\mathrm{BA}$ systems (Curve 2 in Figure 2), where $m$ is the number of moles of base added per mole of the metal (Figure 2). In addition, the titration curve of the $\mathrm{Cu}$ (II) complex is different from that of the free BA curve. Experimental data has shown that, in the $m=0$ to $\sim 2.2$ buffer zone, the $\mathrm{CuL}$ complex forms between $\mathrm{pH}=6.0-11.0$.

The potentiometric titrations of the $1: 2 \mathrm{Cu}(\mathrm{II})$-BA systems were carried out under the same experimental conditions. In these curves, two inflection points were observed at $m=3.0$ and $m=5.0$. The titration of these protons in each of these systems indicates that the $\mathrm{CuL}_{2}$ complex forms gradually.

The potentiometric titrations of the $1: 3 \mathrm{Cu}(\mathrm{II})$-BA systems were carried out under the same experimental conditions. In these curves, two inflection points were observed at $m=4.0$ and $m=5.0$. The titration of these protons in each of these systems indicates that the $\mathrm{CuL}_{3} \mathrm{H}$ complex forms gradually. In the 1:3 molar ratio potentiometric titrations, the stability constants of the complexes $\mathrm{CuL}, \mathrm{CuL}_{2}$, and $\mathrm{CuL}_{3} \mathrm{H}$ were calculated by the BEST computer program [22]. The stability constants of their complexes are given in Table 1.

The distribution diagrams were drawn in the titration where the metal to ligand mole ratio was $1: 3$. They were obtained with the aid of SPE program [22] and the concentration of total metal ion presents $\sim 2 \times 10^{-3} \mathrm{M}$ set at $100 \%$. 


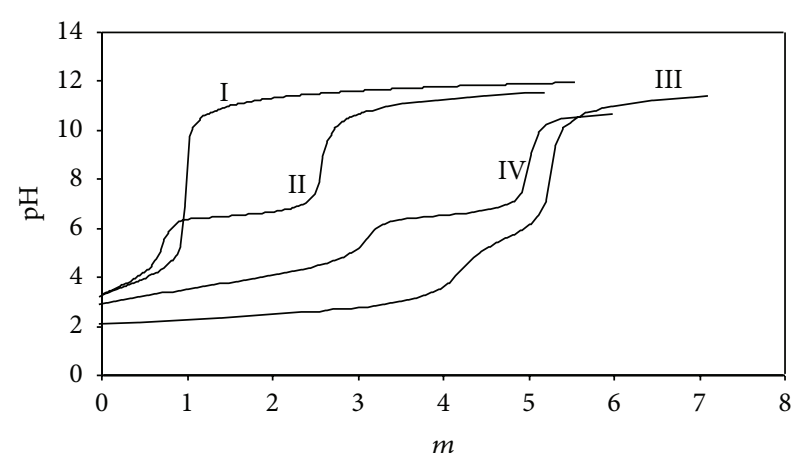

FIgURE 2: Potentiometric $\mathrm{pH}$ profiles for solutions containing (I) $\mathrm{BA}, T_{\mathrm{BA}}=2.0 \times 10^{-3} \mathrm{M}$ and $\mathrm{Cu}(\mathrm{II})$ and $\mathrm{BA}$ in the ratios, (II) $1: 1$ $\left(T_{\mathrm{Cu}}=2.0 \times 10^{-3} \mathrm{M}\right.$ and $\left.T_{\mathrm{BA}}=2.0 \times 10^{-3} \mathrm{M}\right)$, (III) $1: 2\left(T_{\mathrm{Cu}}=2.0 \times\right.$ $10^{-3} \mathrm{M}$ and $\left.T_{\mathrm{BA}}=4.0 \times 10^{-3} \mathrm{M}\right)$, and (IV) $1: 3\left(T_{\mathrm{Cu}}=2.0 \times 10^{-3} \mathrm{M}\right.$ and $\left.T_{\mathrm{BA}}=6.0 \times 10^{-3} \mathrm{M}\right)$, respectively, $T=25.0 \pm 0.1^{\circ} \mathrm{C}$ and $I=0.1$ $\mathrm{MKNO}_{3}$.

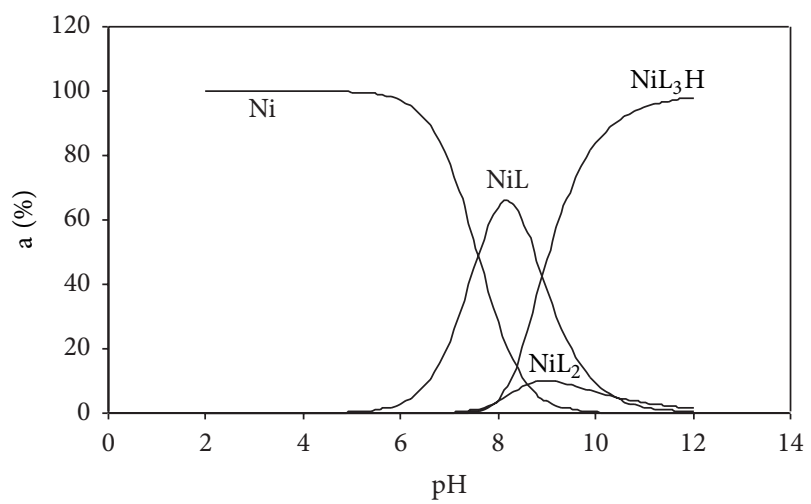

FIgURE 3: Species distribution curves of the metal ion $\mathrm{Ni}(\mathrm{II})$ and the $\mathrm{BA}$ as a function of $\mathrm{pH}$, for a solution initially containing $T_{\mathrm{Ni}}=$ $2.0 \times 10^{-3} \mathrm{M}$ metal ion and $T_{\mathrm{BA}}=6.0 \times 10^{-3} \mathrm{M}$ BA. $T=25.0 \pm 0.1^{\circ} \mathrm{C}$ and $I=0.1 \mathrm{MKNO}_{3} . \%$ a is the percentage of a species present, with the concentration of the metal set at $100 \% ; \mathrm{NiL}, \mathrm{NiL}_{2}$, and $\mathrm{NiL}_{3} \mathrm{H}$ are the complexed species with one, two, and three ligand molecules.

In Figure 4, the species $\mathrm{CuL}_{3} \mathrm{H}$ for the system BA and metal ion $\mathrm{Cu}(\mathrm{II})$ reaches a maximum of $90 \%$ at $\mathrm{pH} 12,0$. The second species $\mathrm{CuL}_{2}$ reaches a maximum of $60 \%$ at $\mathrm{pH} 6,0-12,0$ and the $\mathrm{CuL}$ complex species in the ratio of 1 moles of ligand to one mole metal presents a maximum of $90 \%$ near $\mathrm{pH} 4.0-$ 10.0 .

It can be observed that the stability constants of the $\mathrm{Ni}(\mathrm{II})-\mathrm{BA}$ complexes are lower than $\mathrm{Cu}(\mathrm{II})-\mathrm{BA}$ complexes.

\section{Conflict of Interests}

The authors declare that there is no conflict of interests regarding the publication of this paper.

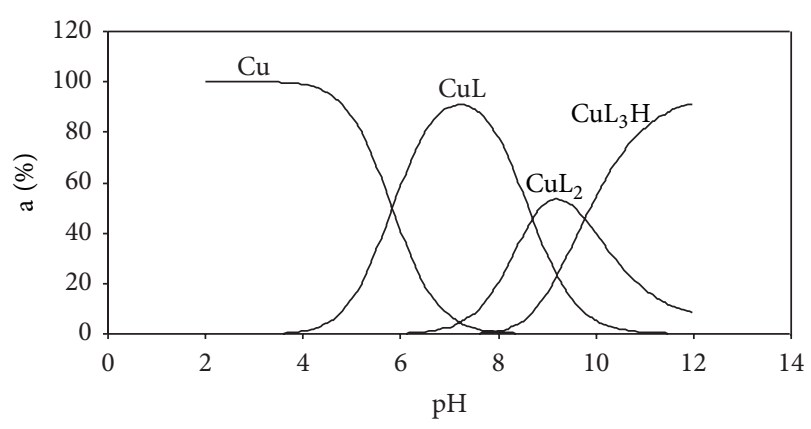

FIgure 4: Species distribution curves of the metal ion $\mathrm{Cu}(\mathrm{II})$ and the $\mathrm{BA}$ as a function of $\mathrm{pH}$, for a solution initially containing $T_{\mathrm{Cu}}=$ $2.0 \times 10^{-3} \mathrm{M}$ metal ion and $T_{\mathrm{BA}}=6.0 \times 10^{-3} \mathrm{M} \mathrm{BA} . T=25.0 \pm 0.1^{\circ} \mathrm{C}$ and $I=0.1 \mathrm{MKNO}_{3} . \%$ a is the percentage of a species present, with the concentration of the metal set at $100 \%$; $\mathrm{CuL}$, and $\mathrm{CuL}_{2}, \mathrm{CuL}_{3} \mathrm{H}$ are the complexed species with one, two, and three ligand molecules.

\section{Acknowledgment}

The authors thank the Research Fund of Uludag University for the financial support given to the research projects (Project no. UAP(F)-2011/70).

\section{References}

[1] F. Hueso-Ureña, N. A. Illán-Cabeza, M. N. Moreno-Carretero, J. M. Martínez-Martos, and M. J. Ramírez-Expósito, "Synthesis and spectroscopic studies on the new Schiff base derived from the $1: 2$ condensation of 2,6-diformyl-4-methylphenol with 5aminouracil (BDF5AU) and its transition metal complexes: influence on biologically active peptides-regulating aminopeptidases," Journal of Inorganic Biochemistry, vol. 94, no. 4, pp. 326-334, 2003.

[2] M. S. Refat, S. A. El-Korashy, and A. S. Ahmed, "A convenient method for the preparation of barbituric and thiobarbituric acid transition metal complexes," Spectrochimica Acta A, vol. 71, no. 3, pp. 1084-1094, 2008.

[3] A. Tsunoda, M. Shibusawa, Y. Tsunoda, N. Yasuda, K. Nakao, and M. Kusano, "A model for sensitivity determination of anticancer agents against chemically-induced colon cancer in rats," Anticancer Research, vol. 14, no. 6B, pp. 2637-2642, 1994.

[4] E. S. Raper, "Complexes of heterocyclic thione donors," Coordination Chemistry Reviews, vol. 61, pp. 115-184, 1985.

[5] J. S. Casas, E. E. Castellano, M. D. Couce et al., "A gold(I) complex with a vitamin $\mathrm{K}_{3}$ derivative: characterization and antitumoral activity," Journal of Inorganic Biochemistry, vol. 100, no. 11, pp. 1858-1860, 2006.

[6] M. J. M. Campbell, "Transition metal complexes of thiosemicarbazide and thiosemicarbazones," Coordination Chemistry Reviews, vol. 15, no. 2-3, pp. 279-319, 1975.

[7] M. C. Rodriguez-Argüelles, M. B. Ferrari, G. G. Fava et al., "2,6-Diacetylpyridine bis(thiosemicarbazones) zinc complexes: synthesis, structure, and biological activity," Journal of Inorganic Biochemistry, vol. 58, no. 3, pp. 157-175, 1995.

[8] J. S. Casas, M. S. García-Tasende, C. Maichle-Mössmer et al., "Synthesis, structure, and spectroscopic properties of acetato (dimethyl) (pyridine-2-carbaldehydethiosemicarbazonato)tin(IV) acetic acid solvate, [SnMe $\left.\mathrm{SPyTS}_{2}(\mathrm{OAc})\right]$.HOAc. Comparison of its biological activity with that of some struc- 
turally related diorganotin(IV) bis (thiosemicarbazonates)," Journal of Inorganic Biochemistry, vol. 62, no. 1, pp. 41-55, 1996.

[9] M. B. Ferrari, G. G. Fava, P. Tarasconi, R. Albertini, S. Pinelli, and R. Starcich, "Synthesis, spectroscopic and structural characterization, and biological activity of aquachloro(pyridoxal thiosemicarbazone) copper(II) chloride," Journal of Inorganic Biochemistry, vol. 53, no. 1, pp. 13-25, 1994.

[10] U. Koch, B. Attenni, S. Malancona et al., "2-(2-Thienyl)-5,6dihydroxy-4-carboxypyrimidines as inhibitors of the hepatitis $C$ virus NS5B polymerase: discovery, SAR, modeling, and mutagenesis," Journal of Medicinal Chemistry, vol. 49, no. 5, pp. 1693-1705, 2006.

[11] W. Beck and N. Kottmair, "Neue Übergangsmetallkomplexe mit Nuclein-Basen und Nucleosiden," Chemische Berichte, vol. 109, no. 3, pp. 970-993, 1976.

[12] N. Kottmair and W. Beck, "Tungsten carbonyl complexes of $2^{\prime}, 3^{\prime}$-O-isopropylideneguanosine and 6-mercaptopurine," Inorganica Chimica Acta, vol. 34, pp. 137-144, 1979.

[13] A. Ashnagar, N. G. Naseri, and B. Sheeri, "Novel synthesis of barbiturates," Chinese Journal of Chemistry, vol. 25, no. 3, pp. 382-384, 2007.

[14] J. N. Delgado, W. A. Remers, and J. B. Lippincott, Eds., Wilson and Gisvold's Textbook of Organic Medicinal Pharmaceutical Chemistry, Williams \& Wilkins, Philadelphia, Pa, USA, 9th edition, 1991.

[15] J.-L. Fillaut, I. de Los Rios, D. Masi, A. Romerosa, F. Zanobini, and M. Peruzzini, "Synthesis and structural characterization of (carbene)ruthenium complexes binding nucleobases," European Journal of Inorganic Chemistry, vol. 2002, no. 4, pp. 935942, 2002.

[16] Ö. Temiz-Arpaci, A. Özdemir, I. Yalçin, I. Yildiz, E. AkiŞener, and N. Altanlar, "Synthesis and antimicrobial activity of some 5-[2-(morpholin-4-yl) acetamido] and/or 5-[2(4-substituted piperazin-1-yl)acetamido]-2-(p-substituted phenyl)benzoxazoles," Archiv der Pharmazie, vol. 338, no. 2-3, pp. 105-111, 2005.

[17] T. W. G. Solomons and C. B. Fryhle, Organic Chemistry, John Wiley \& Sons, Hoboken, NJ, USA, 9th edition, 2008.

[18] J. H. Block and J. M. Beale, Wilson and Gisvold's Textbook of Organic Medicinal and Pharmaceutical Chemistry, Lippincott Williams \& Wilkins, Philadelphia, Pa, USA, 11th edition, 2004.

[19] W. O. Foye, T. L. Lemke, and D. A. Williams, Principles of Medicinal Chemistry, Williams \& Wilkins, Philadelphia, Pa, USA, 4th edition, 1995.

[20] N. M. Korotchenko and N. A. Skorik, "Interaction of copper(II) and iron(III) with barbituric acid," Russian Journal of Inorganic Chemistry, vol. 45, no. 12, pp. 1945-1948, 2000.

[21] G. Schwarzenbach and H. Flaschka, Complexometric Titrations, Interscience, New York, NY, USA, 1969.

[22] A. E. Martell and R. J. Motekaitis, Determination and Use of Stability Constants, Wiley-VCH, New York, NY, USA, 1989.

[23] M.-J. Blais, O. Enea, and G. Berthon, "Relations structureréactivité grandeurs thermodynamiques de protonation d'h'et'erocycles saturés et non saturés," Thermochimica Acta, vol. 20, no. 3, pp. 335-345, 1977. 

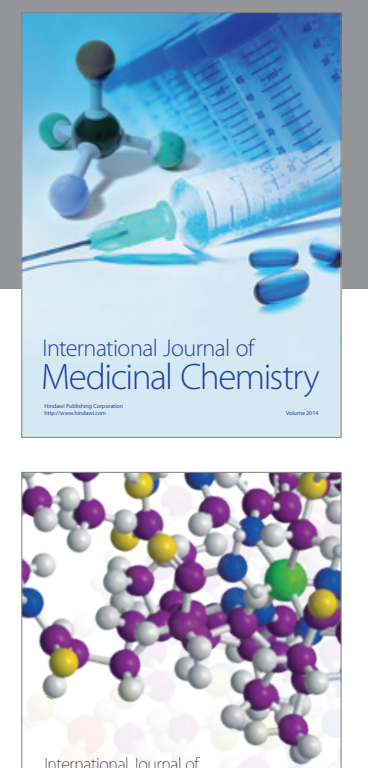

\section{Carbohydrate} Chemistry

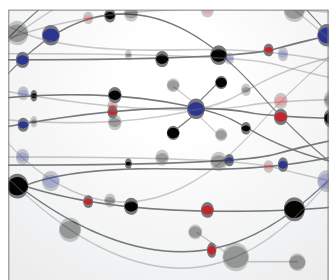

The Scientific World Journal
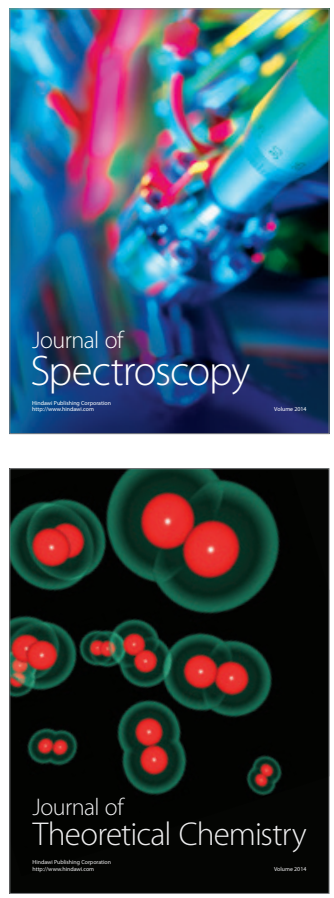
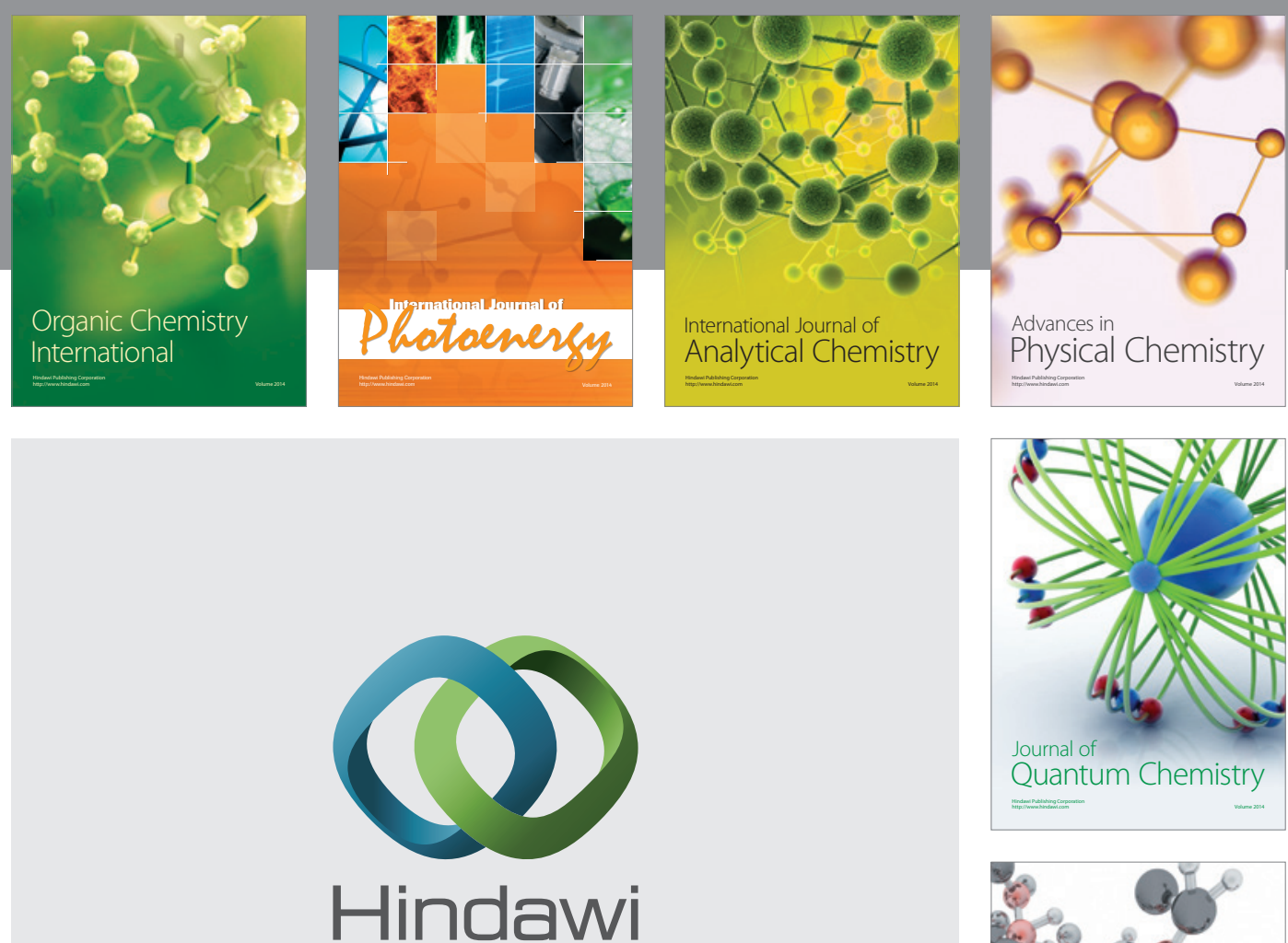

Submit your manuscripts at

http://www.hindawi.com

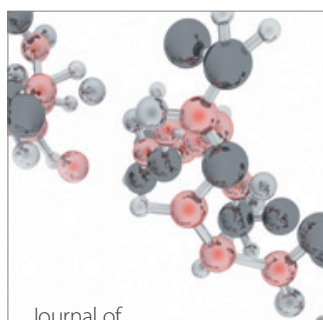

Analytical Methods

in Chemistry

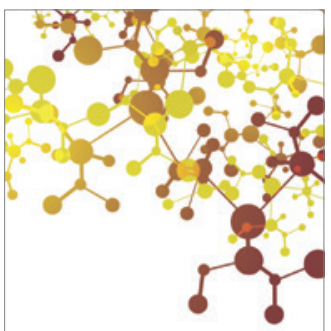

Journal of

Applied Chemistry

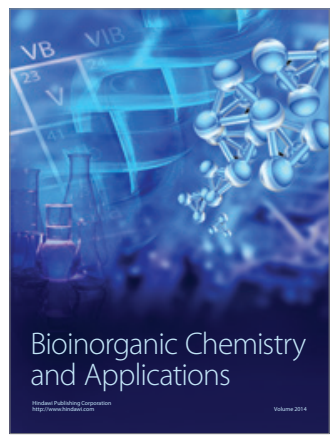

Inorganic Chemistry
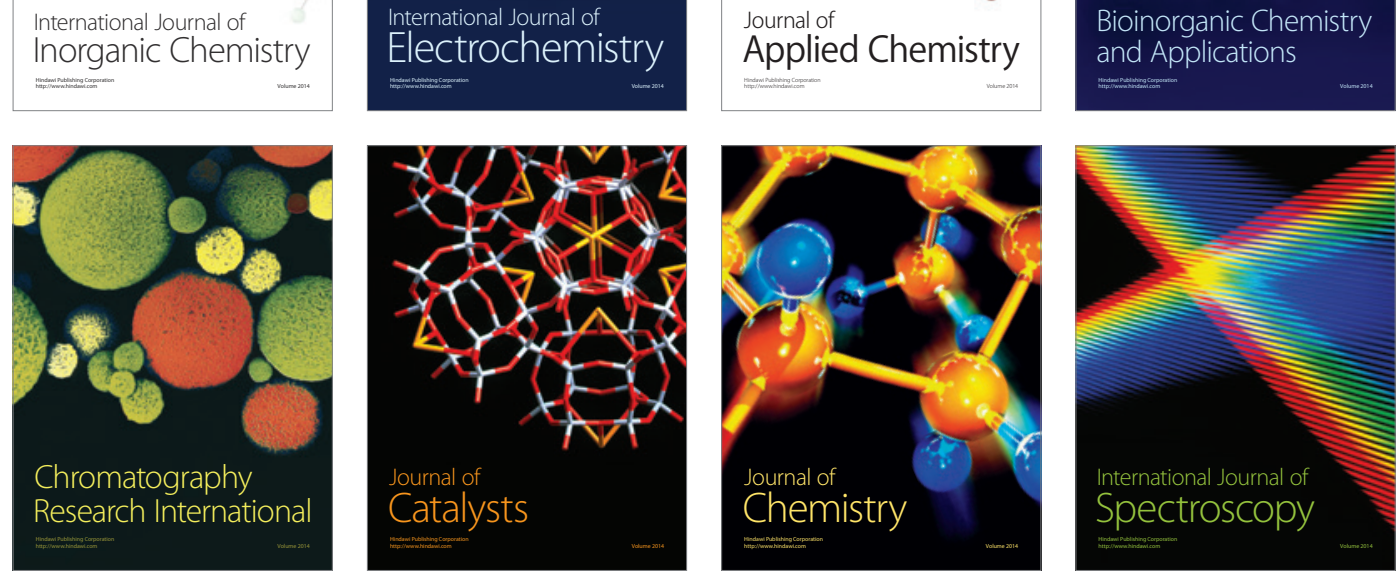